NBER WORKING PAPER SERIES

MINING SURPLUS: MODELING JAMES A. SCHMITZ'S LINK BETWEEN COMPETITION AND PRODUCTIVITY

Jeremy Greenwood

David Weiss

Working Paper 19556

http://www.nber.org/papers/w19556

\author{
NATIONAL BUREAU OF ECONOMIC RESEARCH \\ 1050 Massachusetts Avenue \\ Cambridge, MA 02138 \\ October 2013
}

The views expressed herein are those of the authors and do not necessarily reflect the views of the National Bureau of Economic Research.

NBER working papers are circulated for discussion and comment purposes. They have not been peerreviewed or been subject to the review by the NBER Board of Directors that accompanies official NBER publications.

(C) 2013 by Jeremy Greenwood and David Weiss. All rights reserved. Short sections of text, not to exceed two paragraphs, may be quoted without explicit permission provided that full credit, including (C) notice, is given to the source. 
Mining Surplus: Modeling James A. Schmitz's Link Between Competition and Productivity Jeremy Greenwood and David Weiss

NBER Working Paper No. 19556

October 2013

JEL No. E13,J51,O47

\begin{abstract}
$\underline{\text { ABSTRACT }}$
James A. Schmitz (2005) documents, in a well-known case study, a dramatic rise in productivity in the U.S. and Canadian iron-ore industry following an increase in competition from Brazil. Prior to the increased competition, the industry was not competitive. Surplus in profits was divided between business and unions. Schmitz attributes the increase in productivity to a change in work practices in the industry, as old negotiated union work rules were abandoned or modified. This research formalizes a mechanism through which a rise in competition can lead to increased productivity in the iron-ore industry.
\end{abstract}

Jeremy Greenwood

Department of Economics

University of Pennsylvania

3718 Locust Walk

McNeil Building, Rm 160

Philadelphia, PA 19104-6297

and NBER

David Weiss

The Eitan Berglas School of Economics

Tel Aviv University

P.O.B. 39040

Ramat Aviv, Tel Aviv, 69978

Israel

davidweiss@post.tau.ac.il 


\title{
Mining Surplus: Modeling James A. Schmitz's Link Between Competition and Productivity
}

\author{
Jeremy Greenwood and David Weiss \\ University of Pennsylvania and Tel Aviv University*
}

\begin{abstract}
James A. Schmitz (2005) documents, in a well-known case study, a dramatic rise in productivity in the U.S. and Canadian iron-ore industry following an increase in competition from Brazil. Prior to the increased competition, the industry was not competitive. Surplus in profits was divided between business and unions. Schmitz attributes the increase in productivity to a change in work practices in the industry, as old negotiated union work rules were abandoned or modified. This research formalizes a mechanism through which a rise in competition can lead to increased productivity in the iron-ore industry.
\end{abstract}

Keywords: bodies, effort, James A. Schmitz, iron ore, membership, monopoly profits, Nash bargaining, productivity, unions

JEL nos: E13, J51 and O47

\section{Introduction}

In a thought-provoking case study, James A. Schmitz documents how an increase in competition in the U.S. and Canadian Iron-Ore Industries, due to the entrance of Brazilian ore, led to large increases in productivity. The story is striking. Over the course of a few years, increased competition caused prices in the iron-ore industry to fall by $55 \%$. While output initially fell by some $30 \%$, it quickly returned to $92 \%$ of it's pre-crisis level. Real wages fell by $7 \%$, but by $25 \%$ relative to pre-crisis trend. Simultaneously, labor productivity rose

${ }^{*}$ Please address correspondence to David Weiss. Address: The Eitan Berglas School of Economics, Tel Aviv University, P.O.B. 39040, Ramat Aviv, Tel Aviv, 69978, Israel. Email: davidweiss $\otimes$ post.tau.ac.il. 
by $68 \%$, and measures of total factor productivity (TFP) rose by $42 \%$. In short, a rather large change in the market for iron ore led to a significant increase in various measures of productivity. ${ }^{1}$ He systematically details that these changes were not due to standard reasons, such as adopting new technology or closing inefficient mines, but rather due to reducing overstaffing and loosening workplace rules. The new and old work practices were the result of negotiations between mines and unions.

He ends with a question: if the workplace rules and overstaffing led to lower productivity, why were they implemented in the first place? Simply put, why would a firm choose to be unproductive? A simple model is presented here to answer this question. These firms were experiencing profits due to a lack of competition. The mines faced a unionized workforce. Unions have preferences both over the size of their membership and the utility of their members. The utility of a member is captured both by wages they earn and workplace practices, which dictate how much effort they must expend on the job. The surplus from mines is split between the firm and unions. When competition increases, this surplus shrinks. This leads to a reduction in membership (overstaffing). At the same time, union members exert more effort (due to more efficient workplace rules). Productivity increases.

Schmitz's (2005) case study is important. It suggests that the cost of unions may be larger than a simple Rees (1963) welfare-loss triangle, which computes the deadweight loss that arises from the fact that unionized wages are higher than non-unionized ones. Unions may have a deleterious impact on productivity. There is now a growing literature on the connection between productivity and competition. Holmes and Schmitz (2010) survey the literature on case studies concerning the impact of competition on productivity in particular industries, and discuss mechanisms by which competition affects productivity. One paper that looks at the macroeconomic effects of competition on productivity is Cole and Ohanian (2004). They show how the National Industrial Recovery Act led to a symbiotic relationship arising between firms and unions. Profits and wages in some industry soared, despite the fact that the economy at large was suffering through the Great Depression. Cole, Ohanian, Riascos, and Schmitz (2005) study Latin America, and provide evidence that anticompetitive policies, rather than differences in human capital or other factors, are the main reasons for low productivity in Latin American countries. Last, Dinlersoz, Green-

\footnotetext{
${ }^{1}$ The statistics presented here are for the Canadian iron-ore industry. The experience, and statistics, for the U.S. industry are very similar. One difference between the two countries is that Canada produces a measure for total factor productivity while the United States does not. This explains the focus on Canada here.
} 
wood and Hyatt (2013) present evidence suggesting the unions target young and profitable firms in certification elections, suggesting indeed that unions target firms with extractable surplus, as assumed in this paper.

\section{The Model}

Consider an industry where there is a monopolistic firm and a single union. All workers in the firm are identical and are unions members. Decisions are the outcomes of negotiations between the firm and the union.

\subsection{The Firm}

The firm produces output, $y$, using a constant-returns-to-scale technology that employs capital, labor, and materials. In particular, the production process is described by

$$
y=z l^{\gamma} m^{\nu} k^{1-\gamma-\nu}, \text { with } 0 \leq \gamma, \nu, \gamma+\nu \leq 1
$$

where

$$
f=\phi y .
$$

Here $k$ is the stock of capital, $l$ represents the services of labor, $m$ and $f$ represent the inputs of materials, and $z$ stands for TFP. Observe that the first type of material input, $m$, is allowed substitute in standard fashion with other inputs in response to changes in prices. For example, when labor is expensive, the firm might use better materials and supplies in order to cut back on the workers used in maintenance and repairs. The second type of materials, $f$, represents the fixed amount of some resources that simply must be used to create a certain amount of output. Bentonite and the lumber used for shafting might be such examples. Bentonite is used as a binder for creating iron ore pellets from the processed iron ore that derives from finely crushed taconite rock. These inputs are proportional to scale of the mining operation. The introduction of two types of materials serves to capture the fact that material's share of income is large and relatively constant in the iron-ore industry. By normalizing the price of $f$, relative to output, to 1 , the above formulation is equivalent to:

$$
y=(1-\phi) z l^{\gamma} m^{\nu} k^{1-\gamma-\nu} .
$$


Labor services, $l$, are a function of both the number of workers, or bodies, $b$, and their effort level, $e$. Specifically, $l$ is described by the constant-elasticity-of-substitution (CES) aggregator

$$
l=\left[\eta b^{\epsilon}+(1-\eta) e^{\epsilon}\right]^{\frac{1}{\epsilon}}, \text { with } 0 \leq \eta \leq 1 \text { and } \epsilon \leq 1,
$$

where $\epsilon$ controls the elasticity of substitution, and $\eta$ regulates the relative importance of bodies in production.

The monopolist faces an inverse demand function:

$$
p=\left(\frac{\delta}{y}\right)^{\alpha} \text {, with } 0<\alpha<1 .
$$

Here $y$ is the firm's output, $p$ is the price of output, $\delta$ is a demand parameter, and $\alpha$ controls the elasticity of demand. ${ }^{2}$ Along with union wages, $w$, the price of materials, $q$, and the rental rate on capital, $r$, this gives the firm's profits, $\pi$ :

$$
\pi=\Pi(w, b, e, m, k)=\delta^{\alpha} y^{1-\alpha}-w b-r k-q m .
$$

Since $r$ and $q$ are fixed in the analysis they are suppressed in the function $\Pi$. Also suppressed is the second form of materials, $f$, which is assumed to be taken into account in $y$. Implicitly, the price of these materials relative to the price of the output good is assumed to be one.

\subsection{The Worker}

Workers have preferences over wages, $w$, and the exertion of effort $e$. Preferences are assumed to take the CES form shown below:

$$
U(w, e)=\left[w^{\rho}+(1-e)^{\rho}\right]^{\frac{1}{\rho}}, \text { with } \rho \leq 1
$$

The parameter $\rho$ governs the elasticity of substitution between wages, $w$, and rest, $1-e$. Think about wages as representing consumption. Rest is just the total amount of energy

\footnotetext{
${ }^{2}$ Note that $\alpha$ cannot equal one or expenditures would be equal to $\delta$. This would imply that the firm's revenues are independent of the level of output. The firm would therefore set production arbitrarily low, see (4). Alternatively, one could assume an exogenous price and then put decreasing returns to scale into the production function in order to generate a monopoly profits. The second choice creates a force for productivity to increase whenever production decreases. Schmitz (2005) documents that the rise in productivity is not due to either low productivity mines closing, or existing mines reducing their scale. Given his findings, it may be inappropriate to use a decreasing-returns-to-scale production function.
} 
that a worker has, 1, less the what he expends in effort, $e$.

\subsection{The Union}

There is a union that negotiates on behalf of the workers. It has CES preferences over membership (or bodies), $b$, and worker utility in the union, $U(w, e)$ :

$$
W(w, b, e)=\left[U(w, e)^{\tau}+b^{\tau}\right]^{\frac{1}{\tau}}, \text { with } \tau \leq 1,
$$

where $\tau$ captures the elasticity of substitution.

\subsection{Bargaining}

In order to determine employment, effort, and wages, the firm and union engage in Nash bargaining. The surplus they are bargaining over is the amount of profit that the monopolist can create. Assume the threat point for each party is shutting down operations, with the firm stopping production or the union going on strike. Recall that profits, $\Pi$, are given by equation (4) and union welfare, $W$, is given by equation (6). Given these functional forms, the utilities for the worker and union are bounded below by zero. The firm's profits are also bounded below by zero. The threat points are therefore zero. Let the bargaining weight for the union be given by $\zeta$. The outcome of bargaining is therefore the solution to:

$$
(w, b, e, m, k)=\underset{w, b, e, m, k}{\arg \max }\left[\Pi(w, b, e, m, k)^{1-\zeta} W(w, b, e)^{\zeta}\right], \text { with } 0 \leq \zeta \leq 1 .
$$

The form of this bargaining problem implies that the firm will earn strictly positive profits.

Bargaining between the firm and the union is efficient in the sense that one party cannot do better without hurting the other one. Still, from a societal perspective, things might be better without the union. First, the bargaining process exploits the fact that the firm has market power in the iron-ore business. The firm and union share the resulting monopoly rents. Second, the union places a value on high levels of employment in the iron-ore industry that might not be beneficial for the economy. ${ }^{3}$ It uses some of its rents to increase employment and lower the amount of on-the-job effort required by union members.

\footnotetext{
${ }^{3}$ How the union should value the size of its membership, per se, is unclear. Equation (6) is fairly flexible in this regard. For instance, when $\tau=0$ it says that the union simply cares about the number of members times the utility each member earns. These tastes may not represent the preferences of any particular person in the economy.
} 
The extra workers could be better used elsewhere and union members should put in more effort on the job. ${ }^{4}$

\section{The Mechanism}

The main idea is that any monopoly surplus will be shared by the firm and union. Suppose that profits decrease, say as demand decreases or competition increases. This is modeled as a decrease in the demand parameter, $\delta$, and an increase in the elasticity of demand, $\alpha$ (from $\delta$ to $\delta^{\prime}$ and $\alpha$ to $\alpha^{\prime}$, respectively). As a consequence, there are less rents to be shared between the firm and union. How will firm and union react? To be consistent with the data, the model must match certain trends that were observed during the crisis experienced by the iron-ore industry in the 1980s. Specifically, output, prices, employment, and wages must all decrease, while effort and various measures of productivity should increase. The elasticities of substitution for the worker, firm and union all play important roles in generating the desired response.

The following features help to replicate the trends in the data:

1. Bodies, $b$, and effort, $e$, are substitutes in the monopolist's production function, $\epsilon>0$. Each body costs $w$. A prime way to reduce costs is to cut bodies. In face of the reduction in demand, this feature allows the firm to substitute toward effort and away from bodies, in order to reduce costs and mitigate the decline in rents.

2. Rest, $1-e$, and wages, $w$, are complements in a worker's utility, $\rho<0$. In this situation, the marginal rate of substitution between rest and wages changes (in percentage terms) rapidly with a (percentage) shift in the ratio of rest to wages. To enjoy consumption the worker needs rest, so to speak, and vice versa. Thus, any required reduction in utility should be spread out relatively evenly across rest and wages. This force makes it desirable for workers to decrease their rest, $1-e$, in a fairly lock-step fashion with the decline in wages, $w$.

3. Member's utility, $U$, and membership, $b$, are complements in the union's utility function, $\tau<0$. Here the union is unwilling to trade-off a bigger decline in membership against a smaller decline in a worker's utility, or the other way round. This favors a balanced drop in membership and utility.

\footnotetext{
${ }^{4}$ The fact that the firm is a monopoly implies that too little iron ore is produced in the economy. So, on this account, there may be too little labor input in the iron-ore sector.
} 


\section{Calibration}

The model developed will now be fit to the Canadian data. The choice of Canada over the U.S. is due to the greater availability of data, such as total factor productivity. The industries in the two countries reflect each others experiences closely. There are 14 parameters to be picked, $\alpha, \alpha^{\prime}, r, \zeta, q, \gamma, \rho, \tau, \epsilon, \eta, \delta, \delta^{\prime}, \phi$, and $\nu$. Some are imposed and some are calibrated to the data; this is discussed below. The calibration strategy will focus on two periods in the data, pre and post crisis. The year 1981 will be taken to reflect the pre-crisis era and the post-crisis era, which is taken as an average of the years from 1986 to 1990. The year 1981 is chosen as the pre-crisis year since this is when the data begins. An average of the years 1986 to 1990 is taken to help smooth out volatility in the post-crisis data. It will be assumed that the model is in a steady state for each of these periods. As was discussed earlier, the increase in competition is modeled by a shift in the demand parameters from to from $\delta$ to $\delta^{\prime}$ and $\alpha$ to $\alpha^{\prime}$, respectively. Specifically, demand will fall, as will be represented by a fall in $\delta$, and simultaneously become more elastic, as measured by a rise in $\alpha$.

\subsection{Parameters Set Exogenously}

Four parameters are chosen outside of the calibration routine, namely $r, q, \alpha$, and $\delta$. The rental rate on capital, $r$, is set at $10 \%$, reflecting an $8 \%$ depreciation rate in this industry together with a $2 \%$ net interest rate. The price of materials, $q$, is normalized to be 1 , an innocuous assumption. The parameters $\alpha$ and $\delta$ control the elasticity and level of demand, which are important for monopoly rents. As this is a model of imperfect competition, these two parameters govern the amount of surplus that can be generated. What is most important, however, is the change in these parameters over the course of the crisis. So, $\alpha$ and $\delta$ are selected to be 0.5 and 1.0 to begin with. Then, the Canadian data will be used to determine how these demand parameters shift with the crisis, as reflected by $\alpha^{\prime}$ and $\delta^{\prime}$.

\subsection{Matching Model Moments}

The remaining parameters will be picked to match moments in the model to moments in the data. For the calibration exercise, there are ten parameters to select, $\alpha^{\prime}, \gamma, \rho, \tau, \epsilon, \eta, \delta^{\prime}, \phi, \zeta$ and $\nu$ and there will be ten targets in the data. While all the parameters are jointly determined, what follows is a heuristic discussion of the identification strategy. 
The change in total factor productivity and the change in labor productivity inform on the importance of labor in the production function, $\gamma$, and the willingness of workers to substitute between wages and effort, $\rho$. The willingness of the union to substitute between worker utility and number of employees, along with the bargaining power of the union, speak to labor's share of income, and are chosen to match this statistic both before and after the crisis. The weight of materials in the production function, $\nu$, and the amount of fixed materials per unit of output, $\phi$, are selected to match material's share of income both before and after the crisis. The ability to substitute between bodies and effort in the production function, as reflected by $\epsilon$, is set to match the change in output. The importance of bodies in the production function, $\eta$, is picked to match the change in bodies. The new level of demand, $\delta^{\prime}$, is selected to match the decline in prices, while the change in change in elasticity of demand, $\alpha^{\prime}$, is chosen to match the decline in wages.

\begin{tabular}{lll}
\multicolumn{3}{c}{ TABle 1: Stylized FACTS } \\
\hline \multicolumn{1}{c}{ Target } & Data & Model \\
$\Delta$ Labor Prod & $68 \%$ & $67 \%$ \\
$\Delta$ TFP & $42 \%$ & $42 \%$ \\
$\Delta$ Wages & $-25 \%$ & $-38 \%$ \\
$\Delta$ Output & $-8 \%$ & $-8 \%$ \\
$\Delta$ Bodies (hrs) & $-45 \%$ & $-45 \%$ \\
$\Delta$ Prices & $-51 \%$ & $-51 \%$ \\
Labor's Share (pre) & $20 \%$ & $26 \%$ \\
Labor's Share (post) & $22 \%$ & $20 \%$ \\
Material's Share (pre) & $53 \%$ & $53 \%$ \\
Material's Share (post) & $58 \%$ & $60 \%$ \\
\hline \hline
\end{tabular}


Table 2: Parameter Values

\begin{tabular}{llll}
\hline \hline Param & \multicolumn{1}{c}{ Meaning } & Value & \multicolumn{1}{c}{ Identification } \\
$\alpha$ & Elast. of Dem. (pre) & 0.5 & Exog. \\
$\delta$ & Level of Dem. (pre) & 1 & Exog. \\
$r$ & Cost of Capital & $10 \%$ & $8 \%$ Dep $+2 \%$ \\
$q$ & Rel Price Mat & 1 & Normalization \\
$\gamma$ & Labor Weight & 0.14 & $\Delta$ Labor Prod \\
$\rho$ & Worker CES & -0.37 & $\Delta$ TFP \\
$\tau$ & CES union & -0.18 & Labor's Share (pre) \\
$\zeta$ & Barg. Weight & 0.53 & Labor's Share (post) \\
$\nu$ & Material Weight & 0.52 & Material's Share (pre) \\
$\phi$ & Fixed material cost & 0.45 & Material's Share (post) \\
$\varepsilon$ & Prod Fcn Exponent & 0.94 & $\Delta$ Output \\
$\eta$ & Prod Fcn Wgt Bodies & 0.10 & $\Delta$ Bodies \\
$\delta^{\prime}$ & Level of Dem. (post) & 0.63 & $\Delta$ Prices \\
$\alpha^{\prime}$ & Elast of Dem (post) & 0.73 & $\Delta$ Wages \\
\hline \hline
\end{tabular}

As can be seen in Table 1, the model is able to match the facts quite well. Importantly, the model can match both the rise in labor productivity and measured TFP. This is due to an increase in effort by union members, which increases by a factor of five. (Whether there is any meaning to the units that effort is measured in is unclear.) On this, a report by PaineWebber (1987, p. 1-51) attributed the increase in Minnesota mining labor productivity to factors such as (i) increased flexibility in job classifications, (ii) grouping vacations so that plants are only temporarily shut down, (iii) changes in work assignments, (iv) increased pace of work by labor and management, and (v) rationalizing plant maintenance and repair. For example, negotiated union work practices dictated that when a machine broke down workers had to stand by idlely until a union designated repair man came by, even when a simple fix might work. More flexible work practices, which allows the regular workforce to do minor repairs and servicing, reduces such delay. The model overstates the decline in wages, but matches the decline in bodies, and is able to match the change in prices and output quite well. Importantly, the model matches the level of labor's share of income. This is crucial, given the centrality of labor in the proposed mechanism. Had labor's share been substantially larger (smaller) than the target, the model would have had an easier (harder) time matching the observed productivity changes. Labor's share of 
income rose slightly over the time period. The model predicts a decline, as it over predicts the decline in wages. ${ }^{5}$ Material's share of income is is matched well by the model. It rises slightly in both the data and the model.

The results confirm the intuition from Section 3. Effort and wages are complements in the worker's utility function, with $\rho=-0.36$. Membership and worker utility are also complements in the union's utility function $(\tau=-0.18)$. Finally, bodies and effort are close substitutes in the production function $(\epsilon=0.94)$. The convex cost to the worker of providing effort implicitly generates an extra form of imperfect substitutability, however; while the firm doesn't care if there are two workers, or one worker exerting twice as much effort, the workers, and hence the union, will care.

\section{Conclusion}

James A. Schmitz (2005) documents the striking response of productivity to changes in the competitive environment of the iron-ore industry. A quantitative model of the interaction between a monopolist and a union is developed here that captures the basic elements of his case study. In the analysis, the monopolist cares about its profits while the union values the both the size of its membership and the utility of its workers. The monopolist and the union bargain over how to split the surplus. When surplus decreases, due to competition, the union is forced into accepting reduced overstaffing and increasing worker effort, resulting in higher productivity. The mechanisms that allow for the model to match the data are explored. Key considerations in the analysis are: (i) the union's willingness to trade off membership and the welfare of its workers; (ii) the substitutability of bodies and effort in production; and (iii) the form of workers' preferences over wages and on-the-job effort. The model can match both the increase in labor productivity and the rise in total factor productivity that are observed in the data.

\section{Data Sources}

Data comes from two sources. First, James A. Schmitz, generously shared the data set for his case study. Second, some data is taken from Statistics Canada. The data analysis is

\footnotetext{
${ }^{5} \mathrm{Had}$ the model managed to match the observed decline in wages relative to trend, the decline in labor's share of income would have been halved. Alternatively, had the model matched the actual decline in real wages, rather than the decline relative to trend, labor share of income would have risen by a percentage point more than it did in the data.
} 
Schmitz (2005) is followed as much as possible, with a few exceptions. Data from Statistics Canada is used to compute trends in pre-1980 real wage growth in the Iron Mines industry. ${ }^{6}$ When comparing the real wage change in this time series, relative to trend, to the real wage time series, relative to trend, in Schmitz (2005), the numbers are quite similar (changes of $20 \%$ and 25\%, respectively). CPI data from Statistics Canada is used as well. The data on depreciation is from Statistics Canada. It an average of the depreciation rates in the Iron Mines industry over the time period studied.

Labor's and material's shares of income are also from James A. Schmitz's data. These series are somewhat volatile, but do not appear to have a significant trend. Again, two data periods are focused on: 1981 for the pre-crisis period, and an average of 1986-1990 for the post-crisis period. The specific numbers here are not as important as the general magnitudes and the fact that they did not seem to change much over this time period.

\footnotetext{
${ }^{6}$ See Statistics Canada table 152-0002, variable 617976.
} 


\section{References}

[1] Cole, Harold L. and Lee E. Ohanian. 2004. "New Deal Policies and the Persistence of the Great Depression: A General Equilibrium Analysis," Journal of Political Economy, 112 (4): 779-816.

[2] Cole, Harold L., Lee E. Ohanian, Alvaro Riascos, and James A. Schmitz. 2005. "Latin America in the Rearview Mirror," Journal of Monetary Economics, 52 (1): 69-107.

[3] Dinlersoz, Emin, Jeremy Greenwood and Henry Hyatt. 2013. "Whom do Unions Target? Unionization over the Life-Cycle of U.S. Businesses," U.S. Census Bureau (in process).

[4] Holmes, Thomas, and James A. Schmitz. 2010. "Competition and Productivity: A Review of Evidence," Annual Review of Economics, 2: 619-642.

[5] Marcus, Peter F., Kirsis, Karlis M. and Peter Kakela. 1987. World Steel Dynamics: The Threatened North American Iron Ore Industry: Break-through Analysis. PaineWebber.

[6] Rees, Albert. 1963. "The Effects of Unions on Resource Allocation." Journal of Law and Economics, 6 (2): 69-78.

[7] Schmitz, James A. 2005. "What Determines Productivity? Lessons from the Dramatic Recovery of the U.S. and Canadian Iron Ore Industries Following Their Early 1980s Crisis," Journal of Political Economy, 113 (3): 582-625. 